\title{
DEVELOPING ENGLISH WRITING MATERIALS OF DESCRIPTIVETEXT FOR TENTH GRADE STUDENT BASED ON PROJECT BASED LEARNING AT SMA SWASTA MARISI MEDAN
}

\author{
*Winda Sundari \\ ** Rahmad Husein \\ **Rika
}

\begin{abstract}
This research aimed to find out the target and learning needs of Grade X SMA SWASTA MARISI MEDAN. Moreover, it had a goal to develop English materials for learning writing skills. This is a research and development (R\&D) study. The subjects of this research were 25 students of Grade X SMA SWASTA MARISI MEDAN. The need analysis data were collected by using questionnaires and an interview. Then, the results of questionnaires were calculated through percentage. Thus, the highest percentage was considered as the needs of students. Meanwhile, the results of expert judgment were analyzed in the form of descriptive statistics. Three units of materials were developed in this research. Each unit consists of introduction, main lesson and reinforcement. These materials used Project-Based Learning as the approach in learning writing skill. The units covered some tasks as identify the generic structure, write a short paragraph and complete the sentences. Mostly, the themes used represented students' knowledge about the popular places and person around them. According to the results of the expert judgment, the materials were very relevant to be used for Grade X SMA SWASTA MARISI MEDAN.
\end{abstract}

Keywords: learning writing, writing, descriptive text 
* Graduate Status

**Lecture Status

\section{INTRODUCTION}

\section{Background of the Study}

Writing skill is important to high school students at SMA MARISI SWASTA MEDAN. It plays two distinct roles but complementary. First, it is a skill draws on the use of strategies (such as planning, evaluating, and revising text) to accomplish a variety of goal, such as writing a report or expressing an opinion with the support of evidence. Second, writing is a means of extending and deepening student's knowledge; it acts as a tool for learning subject matter (Key, 2000; Shanahan, 2004; Sperling \& Freedman, 2001).

The curriculum in Indonesia requires students to be able to write some kind of text like recount, report, discussion, explanation, expositioin, new item, anecdote, narrative, procedure, description, and review. Decriptive text is one of the genres taught for tenth grade students at Senior High School. In the syllabus of curriculum 2013 there are three types of text that should be taught at tenth grade students, they are descriptive text, recount text and narrative text.

Based on the researcher's observation to the English teacher on teaching learning process, The English teacher uses the book entitled is Bahasa Inggris Kelas $X$ in SMA Swasta Marisi Medan especially in tenth grade students. She uses the brainstorming strategy and she just focuses on using the text book by giving the student an assignment. Students feel bored to do the assignments because it only answers the questions from the texts. It does not give students a motivation to write. The strategy is not effective to improve the student's writing skill.

Based on the students' exercise about writing an E-mail, the researcher found the problems related to writing skill. First, they got confuse to develop their ideas in writing a text. They feel confused to start writing. Second, they found difficulties in choosing the words suitable for their writing into good sentences and good paragraph because of their lack of vocabulary. In this case, there is an alternative way to solve 
the problem. That is Project Based Learning. It can help the students to improve their writing skill. Project Based Learning puts students in a position to use the knowledge that they get, effective in helping students understand, apply, and retain information.

Based on the research finding, the writer concludes that by using Project Based Learning, the student get motivation in learning writing because Project Based Learning gives them new experience in teaching learning process. Project Based Learning guides the students to develop their idea in writing and apply it in project.

The teacher in SMA Swasta Marisi Medan has applied one of the techniques, that is guided-questions. Then, the students are able to start writing easily by answering the questions. So, in the reseacher's opinion in this case, the teacher had to give the interesting materials that could reduce and solve the problems with that technique.

It is necessary for the teacher to design interesting materials. The materials should provide students' needs an interest. Materials are useful to make students easier to catch the subject. There are many alternatives techniques used by teacher. Design interesting writing materials with based on project based learning model. It is one of learning models that can solve that problem. Therefore, it is necessary to provide suitable and interesting materials for students of tenth grade students at SMA SWASTA MARISI MEDAN to encourage them to practice writing.

\section{REVIEW OF LITERATURE}

Writing is one of the most important skills in studying English. Writing is not easy ability to do. In writing, learner should have basic ability that is ability in developing the ideas, words and arranging them into good sentences. It is become something difficult for many learners where they get difficulty in start a written. The important aspect when done writing is an idea then supported by rich vocabularies.

That is why can make a beautiful sentence. There are some definitions of writing by experts. It is unique. Based on Harmer (2004:31) states that Writing encourage 
students to focus on accurate language use and because they think as they write, it will provoke language development as they resolve problems which the writing puts into their minds. In line with that Christina R \& Robert L Mc. Donald in Richard M. Coe (2002:7) point out that Writing is usefully described as a process, something which shows continuous change in time like growth in organic nature. Different things happen at different stages in the process of putting thought into words and words onto paper.

In English teaching and learning process, a material is one of important factors that have to be prepared. Tomlinson (1998: 2) states that materials can be defined as anything which is used by teachers or learners to facilitate the learning of a language and it could obviously be cassettes, videos, CD-rooms, dictionaries, grammar books, newspaper, and so on. It also can be said that everything can be used as the materials in the learning process as long as they give positive effects in increasing students ${ }^{\text {ee }}$ knowledge.

Hutchinson and Waters (1987: 107-108) propose six criteria of good materials. First, materials provide a stimulus for learning. Good materials do not teach but encourage learners to learn. Second, materials help to organize the teaching learning process, by providing a path through the complex mass of the language to be learnt. Good materials should provide clear and coherent unit structure which will help students in understanding the lesson through various tasks. Third, materials embody a view of the nature of language and learning. They should reflect about the learning process and content of the lessons. Forth, materials reflect the nature of the learning task. Materials should show some kind of tasks from the simple one to the most complex. Fifth, materials can have a very useful function in broadening the basis of teacher training by introducing teachers to new techniques. Finally, materials provide models at correct and appropriate language use. Giving authentic examples in each topic is very useful for the students. It has made them easier to understand what the purpose of the lessons. 
Project-based learning (PBL) is a model that organizes learning around projects. According to the definitions found in PBL handbooks for teachers, projects are complex tasks, based on challenging questions or problems, that involve students in design, problem-solving, decision making, or investigative activities; give students the opportunity to work relatively autonomously over extended periods of time; and culminate in realistic products or presentations (Jones, Rasmussen, \& Moffitt, 1997; Thomas, Mergendoller, \& Michaelson, 1999).

The George Lucas Educational Foundation(2005) seems to be the most comprehensive procedure and therefore the implementation of PBL in this research employed this procedure. It is explained as follows: (1) Start with the Essential Question, (2) Design a Plan for the Project, (3) Create a Schedule, (4) Monitor the Students and the Progress of the Project, (5) Assess the outcome and (6) Evaluate the Experiences.

\section{RESEARCH METHODOLOGY}

In conducting this research, it was conducted based on educational research and development ( $R$ \& D). R \& D is one of research design aimed at developing and validating educational products, like curriculum, syllabus, textbooks, instructional media, modules, assessment instrument, etc. (Borg \& Gall, 2003). This research would conduct by following six phases of R\&D: (1) analyzing existing syllabus, existing writing materials, and student' need to identify problems, (2) reviewing the theory of principle of effective writing materials, (3) designing syllabus and writing materials, (4) validating new writing materials to the experts, and (5) revising new writing materials as suggested by expert, (6) revised - developing writing materials (final product).

The subject of this research is students which were in tenth grade students at SMA Swasta Marisi Medan which is located on Jalan Guru Sinumba No.2, Medan Helvetia, Kota Medan, Sumatera Utara. The data were collected through questionnaires, interview and observation. The questionnaires was administered to 
get the data of the students and the interview was administered to the teacher to find the accurate data from the teacher about the students' needs especially in writing descriptive text.

\section{Techniques of Analysis Data}

The data of this study was the need for students of SMA Swasta Marisi Medan. The data will be analyzed by getting the solution of the students' problem and the new materials for teaching writing descriptive text. The data was analyzed as follows: Analyzing students' needs by using questionnaire and interview. The questionnaire was administered to get the data of the students and the interview was administered to the teacher. The data was needed to evaluate the writing based on the students' needs of English writing materials. Analyzing all of the documents by the researcher. Then the researcher develops the relevant writing materials based on needs analysis, particularly descriptive text.

\section{RESEARCH FINDING AND DISCUSSION}

The writing materials were developed through 6 phases; 1) Gathering information and data, 2) Analyzing data, 3) Designing new material, 4) Validating new material by experts, 5) Revising new material based on experts' suggestion, 6) Reviseddeveloping new writing materials ( Final Product

\section{Research Finding}

\section{Gathering Information and Data}

Gathering information and data had been done before starting the research. It was supposed to get the problem of study. There were some information gathered, such as the questionnaire, the existing materials, the syllabus, and the teacher's interview. From the information gathered, two problems were found. First, the writing materials in English text book used SMA SWASTA MARISI MEDAN were difficult for students. Second, the materials would be developed which fulfilled the students' needs. Furthermore, the detail information was needed to develop materials 
based on the students' needs. The questionnaires were distributed to 25 grade $\mathrm{X}$ students of SMA SWASTA MARISI MEDAN. After that, interview session was administered to ESL teacher of grade X in SMA SWASTA MARISI MEDAN. The result will be discussed in the next phase.

2. Analyzing Data

The main data in this study were the existing materials and the students' needs. The existing materials were matched to the students' needs based on questionnaire to identify whether the existing materials fitted to the students' needs of not. After that, the analysis of students' need became the guidance for the researcher in developing appropriate English writing materials based on Project Based Learning.

\section{a. Existing Materials}

The existing materials used by students Senior High School in Grade X were identified by administering the documents, and interview to the English teacher. The students used the English textbook Bahasa Inggris kelas X.

As it stated on the background that the curriculum used in this school is curriculum 2013. One of basic competence is write a simply oral and written descriptive text about people, spot and famous historical building by seeing its purpose, social purpose, grammatical features and lexicogrammatical features well based on its context. But the exercises are difficult to the students.

b. Need Analysis

Need analysis was required before developing new writing materials. It could get the needs of students which would be the priority of designing the material from the analysis of questionnaire and teacher's interview.

The questionnaire was distributed to 25 Grade X students of Senior High School at SMA SWASTA MARISI MEDAN.

The complete need analysis questionnaire can be seen on Appendix A.

1. Questionnaire Analysis

Based on the questionnaire, there were three main points included the target's opinions of writing; they were the difficulties of writing, the 
motivation of writing and frequency of students' writing. The following Table 4.1 shows students' opinion of writing.

Table 4.1 the Students' Opinion of Writing

\begin{tabular}{|c|c|c|c|c|}
\hline Question & Items & $\mathbf{N}$ & $\mathbf{F}$ & $\mathbf{P}$ \\
\hline $\begin{array}{l}\text { What is the } \\
\text { common difficulty } \\
\text { that you find when }\end{array}$ & $\begin{array}{l}\text { a. Confuse what I should } \\
\text { write ( there's no idea or } \\
\text { too many ideas ) }\end{array}$ & 25 & 5 & $20 \%$ \\
\hline \multirow[t]{3}{*}{$\begin{array}{l}\text { you write in } \\
\text { English? }\end{array}$} & $\begin{array}{ll}\text { b. } & \text { Mastering of } \\
& \text { vocabulary is low }\end{array}$ & & 11 & $44 \%$ \\
\hline & $\begin{array}{l}\text { c. Using of grammar in } \\
\text { English }\end{array}$ & & 5 & $20 \%$ \\
\hline & $\begin{array}{l}\text { d. Do not know written } \\
\text { criteria in English well }\end{array}$ & & 4 & $16 \%$ \\
\hline \multirow{4}{*}{$\begin{array}{l}\text { Did you motivated } \\
\text { to master writing } \\
\text { skill in English? }\end{array}$} & a. Very motivated & 25 & 7 & $28 \%$ \\
\hline & b. Motivated & & 10 & $40 \%$ \\
\hline & c. A bit motivated & & 8 & $32 \%$ \\
\hline & Did not motivate & & 0 & $0 \%$ \\
\hline \multirow{4}{*}{$\begin{array}{l}\text { How often do you } \\
\text { practice or try to } \\
\text { write in English out } \\
\text { of English lesson } \\
\text { time? }\end{array}$} & a. Always & 25 & 0 & $0 \%$ \\
\hline & b. Often & & 3 & $12 \%$ \\
\hline & c. Sometimes & & 19 & $76 \%$ \\
\hline & $\begin{array}{ll}\text { d. } & \text { Never }\end{array}$ & & 3 & $12 \%$ \\
\hline
\end{tabular}

From the Table 4.1 above, it shows that $44 \%$ of students have difficulties in mastering vocabulary. They are low in vocabulary. It shows that $40 \%$ of students are motivated to master writing skill in English. It shows that $76 \%$ of students sometimes 
do practice or try to write in English out of English lesson time as the frequency of students' writing.

2. Interview Analysis

The interview was administered to the English teacher of SMA SWASTA MARISI MEDAN (Appendix B). It was conducted to support the results of the questionnaire analysis and also to get the accurate data. The result of teacher's interview is that the students' difficulty in writing. In writing, they get confuse to start writing. They only focus on grammar. The teacher's responses to the questions given by the researcher are presented in the table (Appendix B).

By analyzing the data taken both the existing materials and need analysis including the questionnaire and interview English teacher of SMA SWASTA MARISI MEDAN, it was found that the existing writing materials were difficult for Grade X students of SMA SWASTA MARISI MEDAN because the students need the material which is easy to understand as the main principle of Project-Based Learning. Thus, the results of the need analysis were used by the researcher as guidance in developing appropriate English writing materials based on Project-Based Learning for grade X students of SMA SWASTA MARISI MEDAN.

\section{Designing New Materials}

After administering the needs analysis, the appropriate English writing materials based on Project-Based Learning for grade X students of SMA SWASTA MARISI MEDAN were identified. The main point was the English writing materials given should make them easy to develop their writing ability. It was done not only to meet the students' needs in their learning process and also in their future study but also to make the students will be ease in writing activity so that the basic competence and indicator in syllabus could be achieved.

\section{Validating New Materials by Experts}

After the first draft of the materials was developed, the materials were evaluated by the experts to know if the materials had been appropriate or not. The 
evaluation was conducted by giving questionnaires to the experts. There were two validators that asked for validating the materials. They were lecture and teacher in their field. The first validator is Dr. Anni Holila Pulungan, M. Hum. She is a lecturer of English Education Study Program of State University of Medan. She evaluated the materials of writing, it is about the learning objective and the technical writing of the materials. The second validator is Eka Putri Sri Andani, S. Pd. She is an English teacher of SMA Swasta Marisi Medan. She evaluated the learning material of writing, especially about the vocabulary that must be developed. The data of expert's validation score can be seen in table below.

Table 4.2 English Lecturer's Validation Score

\begin{tabular}{|c|c|c|c|}
\hline No. $\quad$ Criterion & $\begin{array}{l}\text { The Number } \\
\text { of Criterion }\end{array}$ & Maximum Score & Scores \\
\hline 1. Linguistics & 8 & 40 & 30 \\
\hline 2. Process & 6 & 30 & 24 \\
\hline 3. Product and Content & 8 & 40 & 34 \\
\hline 4. Layout & 7 & 35 & 29 \\
\hline Total & 29 & 145 & 117 \\
\hline
\end{tabular}

Average $=\frac{117}{29}=4.0$ or Percentage $=\frac{117}{145} \times 100 \%=80.6 \%$

The average score of validation from the first validator was 4.0 or $80.6 \%$ and it categorized as relevant. Thus, the final draft or developed writing materials were valid and appropriate to be used as learning materials for students of Senior High School in Grade X.

The second validation was from English teacher to ensure the writing materials for students of Senior High School in Grade X were valid. 
Table 4.3 English Teacher's Validation Score

\begin{tabular}{llccc}
\hline No. & Criterion & $\begin{array}{c}\text { The Number } \\
\text { of Criterion }\end{array}$ & Maximum Score & Scores \\
\hline 1. & Linguistics & 8 & 40 & 30 \\
\hline 2. & Process & 6 & 30 & 24 \\
\hline 3. & Product and Content & 8 & 40 & 33 \\
\hline 4. & Layout & 7 & 35 & 34 \\
\hline & Total & 29 & 145 & 121 \\
\hline
\end{tabular}

Average $=\frac{121}{29}=4.1$ or percentage $=\frac{121}{145} \times 100 \%=83.4 \%$

The average score of validation was $4.3 \%$ or $83.4 \%$ and it was categorized as relevant. It means that the materials were valid and appropriate to use for students of Senior High School in Grade X at SMA Swasta Marisi Medan.

\section{Revising New Materials Based on Experts' Suggestions}

The new writing materials based on Project Based Learning have been checked by the expert, they are lecturer and English teacher. There are some suggestions and revisions from the experts. The lecturer suggested to revise the learning objective in the materials, in order to make it more connected to the content. She said to revise some technical writing. The English teacher suggested adding more vocabulary in each of lesson.

\section{Revised Developing New Materials (Final Product)}

There were three new developed writing materials. Each of lesson has some exercises; composing a descriptive text; designing project. There are some criterions in developing writing materials and each criterion has score range 1 until 5. Score 1 means bad, score 2 means not enough, score 3 means enough, score 4 means good/ relevant and score 5 means very good/ very relevant. 
The first validation was from English Lecturer who validated the reading materials. There were four criterions which have to be considered whether writing materials were valid or not, they are linguistics, process, product and content, and layout as stated on validation instrument.

\section{Discussion}

The aim of this research was to develop English writing materials especially in descriptive text for tenth grade students based on Project Based Learning at SMA Swasta Marisi Medan by knowing the characteristics of the learning need and target. This research was conducted at SMA Swasta Marisi Medan. In developing writing materials, there were several steps to develop them, those are: 1) Gathering information and data, 2) Analyzing data, 3) Designing new materials based on questionnaire, interview, syllabus and curriculum 2013, and the materials were taken

from some sources, such as internet and book, 4) Validating New Materials by experts, 5) Revising materials, and 6) Final Product.

There were 25 students who participated in this research. The students were asked about their background knowledge, target needs and learning needs about writing materials by using questionnaire. Based on the research findings, the results of need analysis was students needed to have appropriate English writing materials and they needed to improve English writing skill to support their future job.

After designing the materials, the product was validated by the experts. The experts gave some revisions and suggestions on developing the materials. Then, the experts gave the score in validation sheet. Based on the result of the two experts, the average of scores are 4.0 and 4.1 which categorized into very good or relevant.

\section{CONCLUSION AND SUGGESTION}

The conclusion

Based on the need analysis from the questionnaire and the interview, it was concluded that the students of Senior High School in Grade X at SMA Swasta Marisi Medan needed the appropriate materials that can develop their ideas in writing 
descriptive text particularly description of person. The English writing materials was developed in order to increase their knowledge about the general description about person and learn new vocabulary. Then, students know about describe a person, describe a popular place around Medan. To improve the students' ability in writing skill is developing the writing materials based on the Project Based Learning. The materials were designed by using six steps. They were designed to produce the students' project. It put in the last step.

The English Writing materials were developed by using six phases of Research and Development (R\&D), they were; 1) gathering information and data, 2) analyzing data, 3) designing new material, 4) validating new material, 5) revising new material, 6) revised-developing new material.

\section{The Suggestion}

On the basis of the conclusion, some suggestions are proposed to the English teacher, institution and other researchers. For the teacher, the English Teachers should consider the students' needs to choose the learning materials and develop the writing materials if they found the materials were not suitable for the students of Senior High School. For the institution, the institution should supervise the teachers and ensure them that the writing materials supported the students' level and find which appropriate to the students' need. For the other Researchers, the other Researchers should find many references to support in developing writing materials, give the students' chance to deliver their wants in new writing material and make English writing materials more easily for the students of Senior High School.

\section{REFERENCES}

Alice, O., Ann Hogue \& Addison. 1997. Introduction To Academic $\quad$ Writing. 2nd Edition. New York

Brace, I. 2008. Academic writing and genre: A systematic Analysis. London: Continuum. 
Christina R. Mc. Donald \& Robert L.Mc. Donald. 2002. Teaching Writing: Landmarks And Horizon. United State Of America: Southern Illinois University.

Dorothy E. Zemach \& Carlos Islam. 2005. Paragraph Writing: From Sentence To Paragraph.Oxford: Macmillan

Fahmi, Irfan. 2011. Developing students' writing ability of descriptive text through clustering technique. (accessed on 03 ${ }^{\text {rd }}$ March, 2017:8:06 PM)

Fitri Alyani, Rochana. 2016. Developing writing materials by using genre - based approach for the first semester of the tenth grade students at SMA PIRI 1 Yogyakarta. (accessed on $14^{\text {th }}$ april, 2017:7:53 PM)

Harmer, Jeremy. 2004. How To Teach Writing. England: Pearson Education Limited.

Hutchinson, T., and A. Waters. 1987. English for Specific Purpose. London: Cambridge University press.

Idolla Anastasia \& Muhammad Al-Hafizh. 2013. Using Multimedia Storyboard In Teaching Writing A Descriptive Text. Journal of English Language Teaching. Vol 1(2), Serie B

Imelda Wardani, Hasan Basri \& Abdul Waris. 2014. Improving The Ability In Writing Descriptive Text Through Guided-Questions Technique. E-journal of English Language Teaching. Vol 2(1), ISSN 2331-1841

Jill Hadfield \& Charles Hadfield. 2008. Introduction To Teaching English. Newyork. Oxford Universty Press.

Mareta Mutia Chusna, Yosi. 2016. Developing Students' Ability in Writing descriptive text: A case study in SMA NEGERI 1 WONOSARI. (accessed on $03^{\text {rd }}$ March, 2017:7:52 pm)

Mustika, Ulfa. 2013. The Ability of Writing Descriptive text of the tenth grade students of SMA N 2 Kudus in the academic year 2013/ 2014 taught by using estafet writing. (accessed on 14 ${ }^{\text {th }}$ April, 2017: 7:58 pm)

Natalia, L Imanuela. 2016. The Effect of Project-Based Learning to the students' writing ability in Descriptive text. Journal of English Teaching and Research. Vol. 1(1) 
Nunan, D. 1989. Designing Tasks for the Communicative Classroom. Cambridge: Cambridge University Press.

Pardiyono.2007.Teaching Based Writing. Yogyakarta: Andi 3

Putri Haryanti, Ari. 2016. Developing Writing Materials for students of the eighth grade of SMP N 3 Tempel. (accessed on 01 ${ }^{\text {st }}$ April, 2017: 4:33 pm)

Rizki Annisa \& Muhd. Al Hafizh. 2013. Teaching Writing Descriptive Text To Senior High School Students By Using The CSW Game. Journal of Language Teaching. Vol.1(2), Serie A

Siburian, Dr. Tiur Asih. 2013. Improving Students' Achievement On WritingDescriptive Text Through Think Pair Share. International Journal of Language Learning and Applied Linguistics World. Vol.3(3), 30-43

Siti Masitoh \& Dasep Supriyadi. 2015. Improving Students Ability In Writing Descriptive Text Using GBA At The Eighth Grade Students Of SMP ISLAM TERPADU FITRAH INSANI. ELTIN Journal. Vol.3(1)

Thanh Huy, Nguyen. 2015. Problem Affecting Learning Writing Skill of Grade 11 at thong linh high school. Vol. 3(2), 53-69 